\title{
Assessing Caffeine Contents in Tea Infusions Decaffeinated by Hot Water Treatment Using High Performance Liquid Chromatography and Studying the Effects of Mint Leaf Addition to Tea Infusions on Improvement of their Total Polyphenol Contents
}

\author{
Tahere Razzaghi ${ }^{1}$, Maryam Salami* ${ }^{2}$, Mahnaz $_{\text {Qomi }}{ }^{3}$, Maryam Moslehishad $^{4}$ \\ 1- Nutrition and Food Sciences Research Center, Tehran Medical Sciences, Islamic Azad University, Tehran, Iran \\ 2- Department of Food Science and Engineering, College of Agriculture and Natural Resources, University of Tehran, Karaj, Iran \\ 3- Medicinal Chemistry Department, Pharmaceutical Sciences Research Center, Pharmaceutical Sciences Branch, Islamic Azad university, Tehran, Iran \\ 4- Department of Food Science and Technology, Safadasht Branch, Islamic Azad University, Tehran, Iran
}

\section{A B S T R A C T}

Background and Objectives: Due to the health concerns of people about caffeine, several techniques have been developed to remove caffeine from tea; however, these techniques include limitations. The objective of the present study was to remove caffeine from dried tea leaves using hot water treatment.

Materials and Methods: Hot water treatment was used to decaffeinate green and black tea leaves using two stages of brewing. Caffeine of the tea infusions was extracted using liquid-liquid extraction technique and quantified using high performance liquid chromatography. Furthermore, $\mathrm{pH}$, total polyphenol content and antioxidant activity were assessed using electronic pH meter, Folin-Ciocalteu method and ABTS method, respectively. Sensory evaluation was carried out using 5-point hedonic scale test. Tea infusions were prepared within two stages of brewing at 1, 3 and 5 min as primary and 7 min as total brewing times.

Results: After 3 min of primary brewing time, decaffeination rates of Ceylon black, China green and Iranian green teas were assessed as $47.7,81.55$ and $85.99 \%$. Antioxidant activity of these samples included $87.7,85.99$ and $81.55 \%$, while total polyphenol content included $83.03,44.44$ and $37.7 \%$, respectively. In general, $\mathrm{pH}$ and total polyphenol content of decaffeinated tea-mint infusions increased significantly.

Conclusions: Effects of brewing time on caffeine concentration of the tea infusions were revealed in this study. In conclusion, hot water treatment is a safe method and includes a high efficiency for the decaffeination of green and black teas.

Keywords: Tea, Caffeine, Polyphenols, Mint Leaf, HPLC

\section{Introduction}

Tea (Camellia sinensis) is the most popular drink after water. Due to beneficial health effects of tea, it is consumed regularly for approximately $120 \mathrm{~mL}$ per day (1). Tea is a rich dietary source of polyphenols. One of the most important polyphenols in tea is catechin. Up to one-third of the tea dry weight includes catechin and other phenolic compounds such as quercetin, myricetin and kaempferol with high antioxidant capacities (2). Tea polyphenols include a variety of effects on consumer health, including antioxidant, anticancer, antiaging and antiviral effects. The moderate caffeine intake is not possibly harmful for a majority of the healthy adults $(3,4)$. However, regular consumption of excessive amounts of caffeine may include relatively adverse effects such as sleep deprivation, abortion, miscarriage and hypersensitivity $(5,6)$. Furthermore, this may cause health problems in psychiatric patients and other sensitive groups such as reproductive aged women and children (3). Proportion of the caffeine extracted from tea leaves to infusions varies from 51.5 to $85.2 \%$ and tea can be considered one of the major sources of caffeine for heavy tea drinkers (7). Due to the health concerns of people for caffeine, numerous techniques have been developed to remove alkaloids such as caffeine from teas, including use of organic solvents $(8,9)$, activated carbon (10), supercritical $\mathrm{CO}_{2}$ extraction $(11,12)$, microwave enhanced ice water 
extraction under vacuum (5), lignocellulose column (13), poly(acrylamide-co-ethylene glycol dimethylacrylate) as adsorbent (14), microbial or enzymatic system (15) and high-pressure processing (16). Although these methods can remove caffeine from teas, they include limitations such as risk of solvent residue $(15,17)$, expensive equipment $(17)$, long production time or difficult scaling up for industrial production (9). In fact, one of the safest methods for removing caffeine from teas is hot water treatment (17).

Effective factors on tea infusion compositions such as caffeine, total polyphenol content (TPC) and antioxidant activity include grade (particle size) of the tea leaves (18) and various parts of the tea plant (19). Moreover, preparation parameters, including quantities of tea and water (18), infusion time $(1,19)$, and water temperature, have been shown as major factors of tea preparation (18). Since $\mathrm{pH}$ of the black tea is low, tea is considered an acidic drink. A variety of health problems can occur for the body in acidic states. Acidic diets cause diseases such as dental erosions (20), metabolic bone diseases, calcium nephrolithiasis, chronic diseases (21) and risk of overdiagnosing gastroesophageal reflux diseases (22). Mint (Mentha longifolia) is well known for its antioxidant properties. Recent research has shown that mint is a rich source of polyphenols. Polyphenols in mint are phenolic acids such as rosmarinic acid, caffeic acid and ferulic acid with significant health effects such as antiallergenic, anti-inflammatory, antimicrobial and antioxidant properties (23). However, pH of mint is relatively high (20).

Mint herbal tea is used as a hot beverage that is naturally caffeine free (24). Nowadays, consumption of functional food is increasing. Food and food ingredients with potentially positive effects on health in comparison to basic nutritional benefits are called functional foods (25). Due to the health benefits of tea and mint, they can be classified as functional foods (26). Although use of decaffeinated teas is increasing, their safety concerns have not been dismissed. Therefore, development of safe, fast and economical decaffeination methods is currently an important issue for the tea industries (17). The major aims of this study were extracting maximum quantities of caffeine from dried leaves of green and black teas using hot water treatment as a safe method within two brewing stages. Assessing effects of mint leaf addition to the infusions in the second brewing stage on increasing
$\mathrm{pH}$ of decaffeinated infusions and their TPC was another aim of this study.

\section{Materials and Methods}

\section{Materials}

Folin-Ciocalteu reagent (FCR), chloroform, potassium persulfate, sodium carbonate, disodium hydrogen phosphate, sodium dihydrogen phosphate and solvents of the highest purity for HPLC analysis were purchased from Merck, Germany. The ABTS reagent was purchased from Sigma (St. Louis, MO, USA). Deionized water used in the experiments was produced using water deionizer (Younglin Ultra 370 Series, South Korea). China green tea (CGT), Iranian green tea (IGT), Ceylon black tea (CBT), Iranian black tea (IBT) and mint leaves were purchased from local tea shops in Tehran, Iran. Standard solutions of ascorbic acid, caffeine and gallic acid (purity $\geq 99 \%$ ) used as standards were purchased from Merck, Germany. A stock solution $\left(600 \mathrm{mg} \mathrm{L}^{-1}\right)$ of ascorbic acid was prepared by dissolving ascorbic acid in deionized water. Other concentrations $(800,1300$ and $1500 \mathrm{mg} \mathrm{L}^{-1}$ ) were prepared by diluting stock solution with deionized water. A stock solution $\left(20 \mathrm{mg} \mathrm{L}^{-1}\right)$ of caffeine was prepared by dissolving caffeine in deionized water. Other concentrations $(40,100,200$ and $500 \mathrm{mg} \mathrm{L}^{-1}$ ) were prepared by diluting stock solution with deionized water. A stock solution of gallic acid $(0.001 \mathrm{mM})$ was prepared by dissolving gallic acid in deionized water. Other concentrations (0.002, 0.003 and $0.004 \mathrm{mM}$ ) were prepared by diluting stock solution with deionized water.

\section{Preparation of tea infusion samples}

To decrease caffeine content of the tea infusions, tea samples were brewed within two stages. In all stages of tea preparation, water volume and temperature included $100(\mathrm{~mL})$ and $98-100\left({ }^{\circ} \mathrm{C}\right)$, respectively. The ratio of tea leaves to water was constant but the brewing time of tea varied in each stage (Table 1). In Stage 1 (primary brewing stage), boiling deionized water $(100 \mathrm{~mL})$ was added to dry tea $(2 \mathrm{~g})$ using porcelain teapot. This was brewed on steam water at various times (Table 1). Stage 1 was the caffeine extraction stage. In Stage 2 (secondary brewing stage), tea infusion was filtered through filter papers and boiling deionized water $(100 \mathrm{~mL})$ was added to the residues using porcelain teapot. This was brewed on steam water at various times. Then, infusions were filtered through filter papers. Based on internal standard methods (27), the optimal brewing tea time includes 6-7 min. 
Tahere Razzaghi, et al: Antioxidant and total polyphenol contents of decaffeinated tea enriched with mint

Table 1. Preparation of tea and decaffeinated tea-mint infusion samples

\begin{tabular}{|c|c|c|c|c|c|}
\hline $\begin{array}{l}\text { Sample } \\
\text { Type }\end{array}$ & $\begin{array}{l}\text { Sample } \\
\text { No. }\end{array}$ & Tea Weight (g) & Mint Weight (g) & $\begin{array}{c}\text { Stage 1: Primary } \\
\text { Brewing Time } \\
(\mathrm{min})\end{array}$ & $\begin{array}{l}\text { Stage 2: Secondary } \\
\text { Brewing Time (min) }\end{array}$ \\
\hline \multirow{6}{*}{$\begin{array}{c}\text { Ceylon Black } \\
\text { Tea }(\mathrm{CBT})\end{array}$} & $1^{\mathrm{e}}$ & 2 & - & 7 & 0 \\
\hline & 2 & 2 & - & 1 & 6 \\
\hline & 3 & 2 & - & 3 & 4 \\
\hline & 4 & 2 & - & 5 & 2 \\
\hline & 5 & 2 & 0.5 & 5 & 2 \\
\hline & 6 & 2 & 0.75 & 5 & 2 \\
\hline \multirow{6}{*}{$\begin{array}{l}\text { Iranian Black } \\
\text { Tea (IBT) }\end{array}$} & $1^{\mathrm{e}}$ & 2 & - & 7 & 0 \\
\hline & 2 & 2 & - & 1 & 6 \\
\hline & 3 & 2 & - & 3 & 4 \\
\hline & 4 & 2 & - & 5 & 2 \\
\hline & 5 & 2 & 0.5 & 5 & 2 \\
\hline & 6 & 2 & 0.75 & 5 & 2 \\
\hline \multirow{6}{*}{$\begin{array}{c}\text { China Green Tea } \\
\text { (CGT) }\end{array}$} & $1^{\mathrm{e}}$ & 2 & - & 7 & 0 \\
\hline & 2 & 2 & - & 1 & 6 \\
\hline & 3 & 2 & - & 3 & 4 \\
\hline & 4 & 2 & - & 5 & 2 \\
\hline & 5 & 2 & 0.5 & 5 & 2 \\
\hline & 6 & 2 & 0.75 & 5 & 2 \\
\hline \multirow{6}{*}{$\begin{array}{l}\text { Iranian Green } \\
\text { Tea (IGT) }\end{array}$} & $1^{\mathrm{e}}$ & 2 & - & 7 & 0 \\
\hline & 2 & 2 & - & 1 & 6 \\
\hline & 3 & 2 & - & 3 & 4 \\
\hline & 4 & 2 & - & 5 & 2 \\
\hline & 5 & 2 & 0.5 & 5 & 2 \\
\hline & 6 & 2 & 0.75 & 5 & 2 \\
\hline
\end{tabular}

${ }^{\mathrm{e}}$ Control sample

\section{Preparation of decaffeinated tea-mint infusion samples}

By increasing the primary brewing time, TPC in the second tea infusion decreased. The highest decrease in TPC was seen in Sample No. 4. To enrich TPC, mint leaves were added to Sample No. 4 of green and black teas. Decaffeinated tea-mint infusion sample was brewed within two stages (Table 1). In Stage 1, boiling deionized water ( $\mathrm{pH} 4.78$ ) was added to the tea leaves $(2 \mathrm{~g})$ using porcelain teapot and brewed on steam water for 5 min. Stage 1 was the caffeine extraction stage. In Stage 2, the tea infusion was filtered through filter papers and then mint leaves and boiling deionized water were added to the residues using porcelain teapot. This was brewed on steam water for $2 \mathrm{~min}$. The infusion was filtered through filter papers and used as sample.

\section{Antioxidant activity (ABTS assay) of tea infusion samples}

The antioxidant activity of various tea infusions was assessed using ABTS assay (1). The radical cation $\left(\mathrm{ABTS}^{+}\right.$.) was generated by reacting aqueous stock solutions of ABTS (Sigma-Aldrich, Germany) with $\mathrm{K}_{2} \mathrm{~S}_{2} \mathrm{O}_{8}$ at room temperature for $12-16 \mathrm{~h}$ in dark to reach final concentrations of 7 and $2.45 \mathrm{mM}$, respectively. Prior to use, the (ABTS ${ }^{+}$.) stock solution was diluted $\sim 48$-fold with $5 \mathrm{mM}$ phosphate buffer (pH 7.8) to reach an absorbance of $0.7 \pm 0.2$ at $734 \mathrm{~nm}$ (28). Then, $0.015 \mathrm{~mL}$ of tea infusion or appropriately diluted ascorbic acid standard deionized water solution was added to $2.727 \mathrm{~mL}$ of the $\left(\mathrm{ABTS}^{+}\right.$.) solution and mixed well (1). Samples were set at room temperature for $5 \mathrm{~min}$ in dark and the absorbance was read at $734 \mathrm{~nm}$ (T80+ UV/Vis Spectrometer, PG Instruments, UK) (28). The experiment was carried out in triplicate. Values of inhibition were calculated based on the following equation:

(Eq. 1)

Inhibition of A734 (\%) $=(1-\mathrm{Ac} / \mathrm{Ao})-100$

Where, $A_{c}$ was absorbance of the samples and $A_{o}$ was absorbance of the $\left(\mathrm{ABTS}^{+}\right.$.) solution (control). Antioxidant activity was expressed as $\mu \mathrm{g} \mathrm{mL} \mathrm{m}^{-1}$ 
ascorbic acid equivalent using linear regression value from ascorbic acid calibration curves $(29,30)$.

\section{Total polyphenol content of tea infusion samples}

The TPC in tea infusion samples was assessed using FCR (1). Briefly, $0.125 \mathrm{~mL}$ of FCR was added to $1.975 \mathrm{~mL}$ of water followed by the addition of $0.025 \mathrm{~mL}$ of tea infusion. After $10 \mathrm{~min}, 0.375 \mathrm{~mL}$ of $20 \% \mathrm{Na}_{2} \mathrm{CO}_{3}$ was added to the mixture and incubated at room temperature for $2 \mathrm{~h}$ in dark. Gallic acid was used as standard deionized water solution, absorbance was read at $760 \mathrm{~nm}(\mathrm{~T} 80+\mathrm{UV} / \mathrm{V}$ is Spectrometer, PG Instruments, UK) and results were expressed as $\mathrm{mM}$ gallic acid equivalent (GAE).

\section{Caffeine extraction from tea infusion samples}

Infused teas were decaffeinated using liquid-liquid extraction technique. Tea samples $(100 \mathrm{~mL})$ were cooled to room temperature. Then, $20 \mathrm{~mL}$ of the samples were decanted into a separatory funnel and mixed with $10,8,8,8,8$ and $8 \mathrm{~mL}$ of chloroform, respectively. The separatory funnel was gently shaken for $10 \mathrm{~s}$ (31). The solubility of caffeine in chloroform is nine times more than water at room temperature (32). After shaking, two layers were formed in the separatory funnel, including water phase and chloroform phase. After each extraction, the chloroform phase was separated and collected in a flask. Solvent was removed using rotary evaporation (Heidolph LABOROTA 4000eco, Italy) at $270 \mathrm{rpm}$ at $80{ }^{\circ} \mathrm{C}$. Caffeine was achieved in form of white powder. Thin layer chromatography (TLC) was used to check the residues of caffeine, (33). Caffeine was separated on a TLC paper using chloroform-methanol as mobile phase $(0.75 \mathrm{~mL}$ of chloroform and $0.25 \mathrm{~mL}$ of methanol) and visualized under UV light.

\section{High performance liquid chromatography (HPLC) analysis}

The HPLC method was used for the analysis of caffeine in samples (34). Caffeine extracted from the samples was resolved in $50 \mathrm{~mL}$ of $50 \%$ methanol (deionized water:methanol 25:25 v/v) before analysis by HPLC (Younglin YL 9100, South Korea). The HPLC system characteristics included C18 column (5 $\mu \mathrm{m} \times 250 \mathrm{~mm} \times 4.6 \mathrm{~mm}$ ); ultraviolet detector (Younglin YL9120, South Korea); wavelength of 280 $\mathrm{nm}$; sample injection volume of $50 \mu \mathrm{L}$; flow rate of $0.9 \mathrm{~mL} \mathrm{~min}^{-1}$; elution mode of isocratic; mobile phase of $83 \%$ acetic acid:deionized water 6:994 v/v (solvent A), $17 \%$ acetonitrile (solvent B); and time of $10 \mathrm{~min}$.

\section{The pH measurement of tea infusion samples}

The $\mathrm{pH}$ value of decaffeinated tea-mint infusions was measured at room temperature using electronic pH meter (Sana SL-901, Iran).

\section{Sensory evaluation of tea infusion samples}

Sensory evaluation of decaffeinated tea and teamint infusion samples was carried out to compare flavors, colors and astringency qualities of the infusions using Five-Point Test (5PT).

\section{Statistical analysis}

All measurements were carried out in triplicate. Data were expressed as the mean \pm SD (standard error). Data were analyzed using one-way analysis of variance (ANOVA) and SPSS Software v.12 (SPSS INC., Chicago, IL, USA). Duncan's multiple range test was used to assess differences in antioxidant activities, caffeine content, TPC and $\mathrm{pH}$ of the tea samples. Non-parametric Kruskal-Wallis test was used for the comparison of sensory profiles of decaffeinated tea and tea-mint infusion samples. A $p$ value of 0.05 or less was considered as statistically significant.

\section{Results}

\section{Antioxidant activity of tea infusion samples}

Results from ABTS assay are reported in Table 2. By increasing the primary brewing time, antioxidant activity in the second tea infusion decreased. Antioxidant activity of CBT and CGT in Samples Nos. 2 and 3 did not decrease significantly ( $p \geq 0.05$ ), while antioxidant activity in Sample No. 4 decreased significantly $(p<0.05)$, compared to control sample (No. 1). Antioxidant activity of CBT and CGT decreased from $100 \%$ at 7 min of primary brewing time to 55.19 and $45.62 \%$ at $5 \mathrm{~min}$ of primary brewing time $(p<0.05)$, respectively. Furthermore, antioxidant activity of IBT in Sample No. 2 did not decrease significantly $(p \geq 0.05)$, while antioxidant activity of Sample No. 4 decreased significantly ( $p<$ 0.05), compared to control sample. Antioxidant activity of IBT decreased from $100 \%$ at $7 \mathrm{~min}$ of primary brewing time to $12.79 \%$ at $5 \mathrm{~min}$ of primary brewing time $(p<0.05)$. Moreover, antioxidant activity of IGT in Samples Nos. 2, 3 and 4 did not decrease significantly ( $p \geq 0.05$ ), compared to control sample. Antioxidant activity of IGT decreased from $100 \%$ at $7 \mathrm{~min}$ of primary brewing time to $51.33 \%$ at 5 min of primary brewing time $(p \geq 0.05)$. 


\section{Total polyphenol content of tea infusion samples}

The TPC results of tea infusion samples are reported in Table 2. By increasing the primary brewing time, TPC in the second tea infusion decreased, compared to control sample $(p<0.05)$. In CBT, TPC decreased from $100 \%$ in control sample to $30.77 \%$ in Sample No. 4 ( $p<0.05)$. In IBT, TPC decreased from $100 \%$ in control sample to $25 \%$ in Sample No. $4(p<0.05)$. In CGT, TPC decreased from $100 \%$ in control sample to $0 \%$ in Sample No. 4 $(p<0.05)$. In IGT, TPC decreased from $100 \%$ in control sample to $21.31 \%$ in Sample No. $4(p<0.05)$.

\section{Relationships between the total polyphenol content and the antioxidant activity}

Statistically, a positive, significant linear relationship $\left(\mathrm{R}^{2}=0.6212, p<0.05\right)$ was found between the TPC and the antioxidant activity of all samples.

\section{Comparison of total polyphenol content in tea and decaffeinated tea-mint infusion samples}

Results showed when dried tea leaves (black and green) were decaffeinated with a ratio of tea leaves to water of $1: 50(\mathrm{w} / \mathrm{v})$ at $98-100{ }^{\circ} \mathrm{C}$ for $5 \mathrm{~min}$, the caffeine contents of the sample (No. 4) significantly and favorably decreased $(p<0.05)$, compared to control sample. However, loss of polyphenol compounds and antioxidant activity in the final tea infusion samples were inappropriate. To solve these problems, Samples Nos. 5 and 6 were enriched with mint as a rich source of polyphenol compounds and a naturally caffeine free herb (Table 1). For CBT, IBT and CGT, TPC in Samples Nos. 5 and 6 increased significantly, compared to Sample No. $4(p<0.05)$. For IGT, TPC of Sample No. 6 increased significantly, compared to Sample No. $4(p<0.05)$. By adding mint leaves to the second tea infusion sample (Sample No. 4 of green and black tea), TPC in the second tea infusion sample increased, compared to Sample No. 4 (Figure 1). For CBT, TPC of Sample No. 4 increased from $30.77(0.0020 \mathrm{mM} \pm 0.0001)$ to $50.77(0.0033 \mathrm{mM} \pm 0.0002)$ and $67.69 \%(0.0040 \mathrm{mM}$ $\pm 0.0002)$ in Samples Nos. 5 and $6(p<0.05)$, respectively. For IBT, TPC of Sample No. 4 increased from $25(0.0008 \mathrm{mM} \pm 0.0000)$ to $68.75(0.0022 \mathrm{mM}$ $\pm 0.0003)$ and $71.88 \%(0.0023 \mathrm{mM} \pm 0.0001)$ in Samples Nos. 5 and $6(p<0.05)$, respectively. For CGT, TPC of Sample No. 4 increased from $0(0.0000$ $\mathrm{mM} \pm 0.0000)$ to $46.30(0.0025 \mathrm{mM} \pm 0.0000)$ and $51.85 \%(0.0028 \mathrm{mM} \pm 0.0001)$ in Samples Nos. 5 and 6 ( $p<0.05)$, respectively. For IGT, TPC of Sample No. 4 increased from $21.31(0.0013 \mathrm{mM} \pm 0.0001)$ to $27.87(0.0017 \mathrm{mM} \pm 0.0000)$ and $47.54 \%(0.0029 \mathrm{mM}$ $\pm 0.0003)$ in Samples Nos. $5(p \geq 0.05)$ and $6(p<$ $0.05)$, respectively.

Table 2. The means of caffeine content $\left(\mathrm{mg} \mathrm{L}^{-1}\right)$, antioxidant activity $\left(\mu \mathrm{g} \mathrm{m}^{-1}\right)$ and total polyphenol content (mM) of black and green tea infusion samples after treatment with hot water

\begin{tabular}{|c|c|c|c|c|}
\hline $\begin{array}{l}\text { Sample } \\
\text { Type }\end{array}$ & Sample No.* & $\begin{array}{c}\text { Caffeine Content } \\
(\mathrm{mg} / \mathrm{L})\end{array}$ & $\begin{array}{c}\text { Antioxidant Activity } \\
(\mu \mathrm{g} / \mathrm{mL})\end{array}$ & $\begin{array}{l}\text { Total Polyphenol Content } \\
(\mathrm{mM})\end{array}$ \\
\hline \multirow{4}{*}{ Ceylon Black Tea } & $1^{\mathrm{e}}$ & $242.44 \pm 2.63^{\mathrm{a}^{* *}}$ & $1471.81 \pm 3.41^{\mathrm{a}}$ & $0.0065 \pm 0.0002^{\mathrm{a}}$ \\
\hline & 2 & $211.50 \pm 6.88^{\mathrm{b}}$ & $1313.53 \pm 90.02^{\mathrm{a}}$ & $0.0043 \pm 0.0006^{\mathrm{b}}$ \\
\hline & 3 & $126.80 \pm 2.44^{\mathrm{c}}$ & $1290.71 \pm 90.18^{\mathrm{a}}$ & $0.0035 \pm 0.0001^{\mathrm{b}}$ \\
\hline & 4 & $69.32 \pm 3.61^{\mathrm{d}}$ & $812.27 \pm 150.24^{b}$ & $0.0020 \pm 0.0001^{\mathrm{c}}$ \\
\hline \multirow{4}{*}{ Iranian Black Tea } & $1^{\mathrm{e}}$ & $134.53 \pm 5.71^{\mathrm{a}}$ & $1251.90 \pm 20.42^{\mathrm{a}}$ & $0.0032 \pm 0.0001^{\mathrm{a}}$ \\
\hline & 2 & $89.50 \pm 2.00^{\mathrm{b}}$ & $1148.37 \pm 106.44^{\mathrm{a}}$ & $0.0021 \pm 0.0004^{b}$ \\
\hline & 3 & $56.83 \pm 2.59^{c}$ & $658.29 \pm 33.99^{\mathrm{b}}$ & $0.0014 \pm 0.0000^{c}$ \\
\hline & 4 & $10.96 \pm 1.20^{\mathrm{d}}$ & $160.18 \pm 17.13^{c}$ & $0.0008 \pm 0.0000^{c}$ \\
\hline \multirow{4}{*}{ China Green Tea } & $1^{\mathrm{e}}$ & $138.09 \pm 5.52^{\mathrm{a}}$ & $1473.42 \pm 3.50^{\mathrm{a}}$ & $0.0054 \pm 0.0004^{\mathrm{a}}$ \\
\hline & 2 & $105.77 \pm 3.19^{\mathrm{b}}$ & $1406.90 \pm 51.55^{\mathrm{a}}$ & $0.0034 \pm 0.0004^{\mathrm{b}}$ \\
\hline & 3 & $41.88 \pm 0.31^{\mathrm{c}}$ & $1267.02 \pm 189.78^{\mathrm{a}}$ & $0.0024 \pm 0.0001^{\mathrm{c}}$ \\
\hline & 4 & $22.07 \pm 1.04^{\mathrm{d}}$ & $672.24 \pm 36.26^{\mathrm{b}}$ & $0.0000 \pm 0.0000^{\mathrm{d}}$ \\
\hline \multirow{4}{*}{ Iranian Green Tea } & $1^{\mathrm{e}}$ & $119.66 \pm 3.55^{\mathrm{a}}$ & $1241.50 \pm 63.52^{\mathrm{a}}$ & $0.006 \pm 0.0004^{\mathrm{a}}$ \\
\hline & 2 & $43.23 \pm 2.28^{\mathrm{b}}$ & $1057.00 \pm 19.80^{\mathrm{a}}$ & $0.0039 \pm 0.0002^{b}$ \\
\hline & 3 & $14.54 \pm 1.07^{\mathrm{c}}$ & $1012.46 \pm 286.47^{\mathrm{a}}$ & $0.0023 \pm 0.0002^{c}$ \\
\hline & 4 & $10.67 \pm 0.86^{\mathrm{d}}$ & $637.32 \pm 207.84^{\mathrm{a}}$ & $0.0013 \pm 0.0001^{\mathrm{d}}$ \\
\hline
\end{tabular}

"No. 1, $2 \mathrm{~g}$ of tea leaves with $7 \mathrm{~min}$ of primary brewing time (control sample); No. 2, $2 \mathrm{~g}$ of tea leaves with $1 \mathrm{~min}$ of primary brewing time; No. 3, $2 \mathrm{~g}$ of tea leaves with $3 \mathrm{~min}$ of primary brewing time; and No. $4,2 \mathrm{~g}$ of tea leaves with $5 \mathrm{~min}$ of primary brewing time.

${ }^{* *}$ Values with different letters for each sample in the same column are significantly different $(p<0.05)$.

${ }^{\mathrm{e}}$ Control sample 


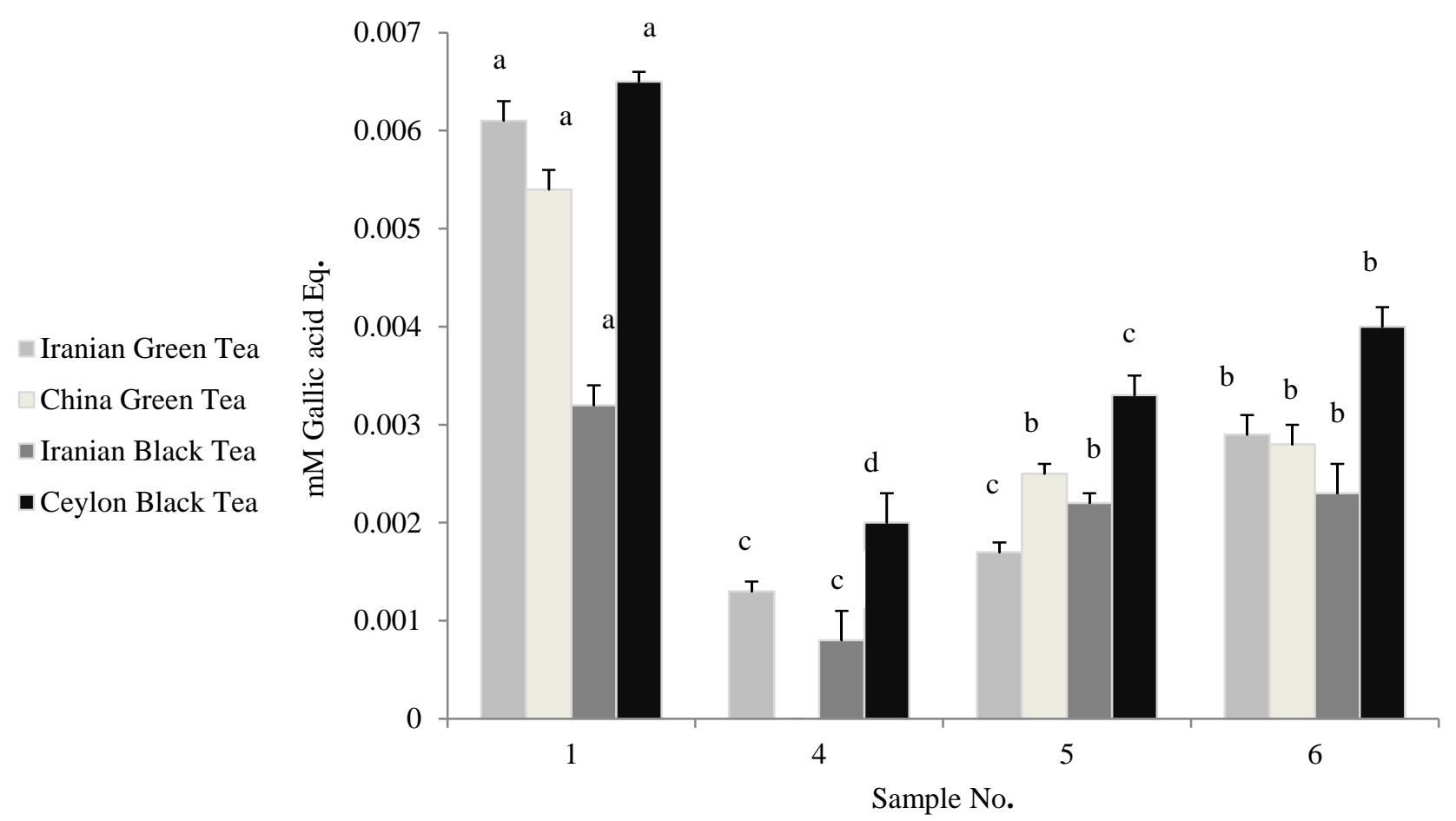

Figure 1. Synergistic effects of mint on phenolic compounds of No. 4 tea infusion sample (tea sample with the highest decaffeination yield). No. 1, $2 \mathrm{~g}$ of tea leaves with $7 \mathrm{~min}$ of primary brewing time (control sample); No. 4, $2 \mathrm{~g}$ of tea leaves with 5 min of primary brewing time; No. $5,2 \mathrm{~g}$ of tea leaves and $0.5 \mathrm{~g}$ of mint leaves with 5 min of primary brewing time; and No. 6, $2 \mathrm{~g}$ of tea leaves and $0.75 \mathrm{~g}$ of mint leaves with $5 \mathrm{~min}$ of primary brewing time. Data with different letters for each sample are significantly different $(p<0.05)$

\section{Caffeine content of tea infusion samples}

Caffeine content of the tea infusions was assessed after using various primary brewing times (Table 2). By increasing the primary brewing time, caffeine residue in the second tea infusion decreased in all samples, compared to control sample $(p<0.05)$. For CBT, caffeine decreased from $100 \%$ in control sample (No. 1) to $28.59 \%$ in Sample No. $4(p<0.05)$. For IBT, caffeine decreased from $100 \%$ in control sample to $8.15 \%$ in Sample No. $4(p<0.05)$. For CGT, caffeine decreased from $100 \%$ in control sample to $15.99 \%$ in Sample No. $4(p<0.05)$. For IGT, caffeine decreased from $100 \%$ in control sample to $8.91 \%$ in Sample No. 4 ( $p<0.05)$.

\section{Effects of mint leaves on $\mathrm{pH}$ of tea infusion samples}

Synergistic effects of mint on $\mathrm{pH}$ of tea infusion samples are shown in Table 3. By adding mint leaves
(pH 6.1) to black and green tea infusion samples (Nos. 5 and 6), the pH increased, compared to control sample $(p<0.05)$.

\section{Sensory evaluation of decaffeinated tea-mint infusion samples}

Assessment of sensory characteristics of decaffeinated tea and tea-mint infusion samples showed that flavor, color and astringency in Sample No. 6 of black tea $(2 \mathrm{~g}$ of tea leaves and $0.75 \mathrm{~g}$ of mint leaves) were better than those in Samples Nos. 4 ( $2 \mathrm{~g}$ of black tea leaves) and 5 ( $2 \mathrm{~g}$ of tea leaves and $0.5 \mathrm{~g}$ of mint leaves). However, these parameters in Sample No. 5 of green tea ( $2 \mathrm{~g}$ of tea leaves and $0.5 \mathrm{~g}$ of mint leaves) were better than those in Samples Nos. 4 ( $2 \mathrm{~g}$ of green tea leaves) and 6 ( $2 \mathrm{~g}$ of tea leaves and $0.75 \mathrm{~g}$ of mint leaves) $(p<0.05)$. 
Tahere Razzaghi, et al: Antioxidant and total polyphenol contents of decaffeinated tea enriched with mint

Table 3. The mean $\mathrm{pH}$ of decaffeinated black and green tea-mint infusion samples

\begin{tabular}{|c|c|c|}
\hline Sample type & Sample No.* & $\mathrm{pH}$ \\
\hline \multirow{3}{*}{ Ceylon Black Tea } & No. $1^{\mathrm{e}}$ & $4.76 \pm 0.001^{\mathrm{c}^{3 *}}$ \\
\hline & No. 5 & $5.18 \pm 0.001^{\mathrm{b}}$ \\
\hline & No.6 & $5.32 \pm 0.001^{\mathrm{a}}$ \\
\hline \multirow{3}{*}{ Iranian Black Tea } & No. $1^{\mathrm{e}}$ & $4.84 \pm 0.001^{\mathrm{c}}$ \\
\hline & No. 5 & $5.34 \pm 0.001^{\mathrm{b}}$ \\
\hline & No.6 & $5.36 \pm 0.002^{\mathrm{a}}$ \\
\hline \multirow{3}{*}{ China Green Tea } & No. $1^{\mathrm{e}}$ & $5.45 \pm 0.001^{\mathrm{c}}$ \\
\hline & No. 5 & $5.69 \pm 0.000^{\mathrm{b}}$ \\
\hline & No.6 & $5.71 \pm 0.001^{\mathrm{a}}$ \\
\hline \multirow{3}{*}{ Iranian Green Tea } & No. $1^{\mathrm{e}}$ & $5.29 \pm 0.002^{\mathrm{c}}$ \\
\hline & No. 5 & $5.67 \pm 0.001^{\mathrm{b}}$ \\
\hline & No.6 & $5.69 \pm 0.001^{\mathrm{a}}$ \\
\hline
\end{tabular}

"No. 1, $2 \mathrm{~g}$ of tea leaves with $7 \mathrm{~min}$ of primary brewing time (control sample); No. $4,2 \mathrm{~g}$ of tea leaves with $5 \mathrm{~min}$ of primary brewing time; No. $5,2 \mathrm{~g}$ of tea leaves and $0.5 \mathrm{~g}$ of mint leaves with $5 \mathrm{~min}$ of primary brewing time; No. $6,2 \mathrm{~g}$ of tea leaves and $0.75 \mathrm{~g}$ of mint leaves with 5 min of primary brewing time.

${ }^{* * *}$ Values with different letters for each sample in the same column are significantly different $(p<0.05)$.

${ }^{\mathrm{e}} \mathrm{Control} \mathrm{sample}$

\section{Discussion}

\section{Antioxidant activity, total polyphenol content and caffeine content of tea infusion samples}

Similar to results from other studies $(1,18)$, results from the current study have shown that chemical compositions of the tea infusions are dependent on the preparation processes. The brewing time is one of the factors affecting concentrations of the components in tea infusions. Several techniques have been developed to remove alkaloids such as caffeine from teas (Table 4). However, these techniques usually include limitations. Of these techniques, decaffeinating tea by hot water treatment within two brewing stages is a safe low cast technique for dried green and fermented black tea leaves. This technique can be used by industries and home consumers.

Based on other studies, decaffeinated teas include the most important components of tea (catechins), because these components cannot completely be extracted from the infusions by hot water treatment (36). However, catechins can be extracted from the infusions and released to hot water at long brewing times (e.g. more than $15 \mathrm{~min}$ ) (37). Therefore, it can be concluded that catechins are preserved in decaffeinated tea leaves. Similar to results of other studies $(38,39)$, the current results have shown that high TPC include positive relationships with antioxidant activity and hence decaffeinated tea and tea-mint infusions include strong antioxidant properties, which are necessary for supporting consumer health.

\section{Effects of mint leave on $\mathrm{pH}$ of tea infusion samples}

Based on the studies, $\mathrm{pH}$ of black teas is low and hence black teas are acidic drinks. The current results have shown that adding mint leaves to black and green tea infusions can decrease acidity of the tea infusions. Deionized water ( $\mathrm{pH} 4.78$ ) can affect $\mathrm{pH}$ of the samples; possibly because water with high $\mathrm{pH}$ changes $\mathrm{pH}$ of the samples to alkaline.

\section{Conclusions}

Assessment of the appropriate primary brewing time is an important factor in this study. However, this time can be various for each type of teas. Generally, 3 min of primary and 4 min of secondary brewing times (Sample No. 3) were appropriate brewing times for the Ceylon black tea (CBT), China green tea (CGT) and Iranian green tea (IGT) samples. For the Iranian black tea (IBT), 1 min of primary and 6 min of secondary brewing times (Sample No. 2) were appropriate brewing times. To drink teas with optimal caffeine, phenolic compounds, antioxidant activity and $\mathrm{pH}$, Sample No. 5 (5 min of primary brewing time followed by $2 \mathrm{~min}$ of secondary brewing time of tea leaves with $0.5 \mathrm{~g}$ of mint leaves) was a healthy choice. In conclusion, addition of mint leaves to tea infusions optimizes the nutritional and sensory quality of tea infusions and increases their potential health benefits. 
Tahere Razzaghi, et al: Antioxidant and total polyphenol contents of decaffeinated tea enriched with mint

Table 4. Techniques to remove caffeine from tea and their limitations

\begin{tabular}{|c|c|c|}
\hline Extraction Method & Result(s) & Limitation(s) \\
\hline $\begin{array}{l}\text { Microwave-Enhanced Ice Water } \\
\text { Extraction Under Vacuum }\end{array}$ & $\begin{array}{l}87.6 \% \text { of caffeine and } 36 \% \text { of } \\
\text { catechins were removed (5). }\end{array}$ & $\begin{array}{l}\text { The loss of the catechins is relatively high. Further studies } \\
\text { need to be conducted to optimize the conditions of the method } \\
\text { for the decaffeination of green tea (35). }\end{array}$ \\
\hline Solvent Extraction & $\begin{array}{l}78.8 \% \text { of caffeine was removed } \\
\text { by using citric acid solution (8). }\end{array}$ & Organic solvents have toxicity effect on consumers $(15,17)$. \\
\hline Activated Carbon (AC) & $\begin{array}{l}80 \% \text { of caffeine was removed } \\
\text { while } 68 \% \text { of the catechins were } \\
\text { retained in green tea }(9) \text {. }\end{array}$ & $\begin{array}{l}\text { Applying this method is difficult to scale up for industrial } \\
\text { production and } \\
\text { the material requirements for the regeneration of the activated } \\
\text { carbon can be fairly expensive (35) }\end{array}$ \\
\hline Supercritical $\mathrm{CO}_{2}$ Extraction & $\begin{array}{l}97.4 \% \text { of caffeine and } 37.8 \% \text { of } \\
\text { epigallocatechin gallate (EGCG) } \\
\text { were removed (11). }\end{array}$ & The process needs expensive equipment (17). \\
\hline Supercritical $\mathrm{CO}_{2}$ Extraction & $\begin{array}{l}70.2 \% \text { caffeine and } 6.2 \% \\
\text { catechins were removed (12). }\end{array}$ & The process needs expensive equipment (17). \\
\hline Lignocellulose Column & $\begin{array}{l}\text { The caffeine/EGCG ratio was } \\
0.696 \text { before lignocellulose } \\
\text { column treatment, but it became } \\
0.004 \text { after the column treatment } \\
\text { (13). }\end{array}$ & They are difficult to use for decaffeination of tea leaf (17). \\
\hline $\begin{array}{l}\text { Poly (Acrylamide-Co-Ethylene } \\
\text { Glycoldimethylacrylate) As } \\
\text { Adsorben of Catechins and } \\
\text { Caffeine }\end{array}$ & $\begin{array}{l}\text { The adsorption capacity of total } \\
\text { catechins was } 3.9-5.2 \text { folds of } \\
\text { caffeine. Caffeine and catechins } \\
\text { were recovered by ethanol (14). }\end{array}$ & $\begin{array}{l}\text { The polymers preferred to adsorb the catechins rather than } \\
\text { caffeine (14). } \\
\text { Organic solvents have toxicity effect on consumers }(15,17) \text {. }\end{array}$ \\
\hline Microbial or Enzymatic Systems & $\begin{array}{l}\text { The literature revealed that } \\
\text { major caffeine degrading strains } \\
\text { belong to Pseudomonas and } \\
\text { Aspergillus (15). }\end{array}$ & $\begin{array}{l}\text { In vitro enzymatic studies for caffeine degradation is not yet } \\
\text { reported (15). Applying this method is difficult to scale up for } \\
\text { industrial production and the conditions of this method must be } \\
\text { strictly controlled ( } 35)\end{array}$ \\
\hline High Pressure Processing & $\begin{array}{l}\text { Extraction using high pressure } \\
\text { processing possessed several } \\
\text { advantages, such as higher } \\
\text { yields, shorter extraction times } \\
\text { and lower energy consumption } \\
\text { (14). }\end{array}$ & Organic solvents have toxicity effect on consumers $(15,17)$. \\
\hline Hot Water Treatment & $\begin{array}{l}83 \% \text { of caffeine was removed, } \\
95 \% \text { of total catechins was } \\
\text { retained in the decaffeinated leaf } \\
\text { (15). }\end{array}$ & $\begin{array}{l}\text { The process is applicable to fresh tea leaf and it is not } \\
\text { appropriate for rolled and fermented leaf or dried green and } \\
\text { black tea (15). }\end{array}$ \\
\hline
\end{tabular}

\section{Financial disclosure}

The authors declare no conflict of interest.

\section{Funding/Support}

This study was financially supported by the Department of Food Sciences and Technology, Faculty of Advanced Sciences and Technology, Pharmaceutical Sciences Branch, Islamic Azad University, Tehran, Iran (IAUPS); and Pharmaceutical Sciences Research Center, Pharmaceutical Sciences Branch, Islamic Azad University, Tehran, Iran (IAUPS)

\section{References}

1. Carloni P, Tiano L, Padella L, Bacchetti T, Customu C, Kay A, et al. Antioxidant activity of white, green and black tea obtained from the same tea cultivar. Food Res Int. 2013; 53(2): 900-8.

2. Yang J, Liu RH. The phenolic profiles and antioxidant activity in different types of tea. IJFST. 2013; 48: 16371.

3. Nawrot P, Jordan S, Eastwood J, Rotstein J, Hugenholtz A, Feeley M. Effects of caffeine on human health. Food Addit Contam. 2003; 20(1): 1-30. 
4. Wolde T. Effects of caffeine on health and nutrition: A Review. FSQM. 2014; 30: 59-65.

5. Lou Z, Er C, Li J, Wang H, Zhu S, Sun J. Removal of caffeine from green tea by microwave-enhanced vacuum ice water extraction. Anal Chim Acta. 2012; 716: 49-53.

6. Vinodh Kumar P, Shruthi BS. Tea: an oral elixir. SAJP. 2014; 3: 9-18.

7. Tfouni SAV, Camara MM, Kamikata K, Gomes FML, Furlan RPZ. Caffeine in teas: levels, transference to infusion and estimated intake. Food Sci. Technol (Campinas). 2018; 38(4): 661-66.

8. Dong JJ, Ye J, Lu JL, Zheng XQ, Liang YR. Isolation of antioxidant catechins from green tea and its decaffeination. Food Bioprod Process. 2011; 89: 62-6.

9. Vuong QV, Golding JB, Nguyen MH, Roach PD. Preparation of decaffeinated and high caffeine powders from green tea. Powder Technol. 2013; 233: 169-75.

10. Ye J, Liang YR, Jin J, Liang HL, Du YY, Lu JL, et al. Preparation of partially decaffeinated instant green tea. J Agric Food Chem. 2007; 55: 3498-502.

11. Park HS, Lee HJ, Shin MH, Lee KW, Lee HY, Kim S, et al. Effects of cosolvents on the decaffeination of green tea by supercritical carbon dioxide. Food Chem. 2007; 105: 1011-17.

12. Sun QL, Hua S, Ye JH, Lu JL, Zheng XQ, Liang YR. Decaffeination of green tea by supercritical carbon dioxide. J Med Plant Res. 2010; 4(12): 1161-8.

13. Sakanaka S. A novel convenient process to obtain a raw decaffeinated tea polyphenol fraction using a lignocellulose column. J Agr Food Chem. 2003; 51(0): 3140-3.

14. Lu JL, Wu MY, Yang XL, Dong ZB, Ye JH, Borthakur $D$, et al. Decaffeination of tea extracts by using poly (acrylamide-co-ethylene glycoldimethylacrylate) as adsorbent. J Food Eng. 2010; 97(4): 555-62.

15. Gokulakrishnan S, Chandraraj K, Gummadi SN. Microbial and enzymatic methods for the removal of caffeine. Enzyme Microb. Technol. 2005; 37(2): 22532.

16. Jun $X$. Caffeine extraction from green tea leaves assisted by high pressure processing. J Food Eng. 2009; 94: 105-9.

17. Liang $\mathrm{H}$, Liang $\mathrm{Y}$, Dong $\mathrm{J}, \mathrm{Lu} \mathrm{J}, \mathrm{Xu} \mathrm{H}$, Wang $\mathrm{H}$. Decaffeination of fresh green tea leaf (Camellia sinensis) by hot water treatment. Food Chem. 2007; 101(4): 1451-6.

18. Astill C, Birch MR, Dacombe C, Humphrey PG, Martin PT. Factors affecting the caffeine and polyphenol contents of black and green tea infusions. J Agric Food Chem. 2001; 49(11): 5340-7.

19. Harbowy ME, Balentine DA. Tea chemistry. Crit Rev Plant Sci. 1997; 16(5): 415-80.
20. Akyuz S, Yarat A. The $\mathrm{pH}$ and neutralisable acidity of the most-consumed Turkish fruit and herbal teas. OHDMBSC. 2010; IX: 75-8.

21. Minich DM, Bland JS. Acid-alkaline balance: role in chronic disease and detoxification. Altern Ther Health Med. 2007; 13: 62-5.

22. Agrawal A, Tutuian R, Hila A, Freeman J, Castell DO. Ingestion of acidic foods mimics gastroesophageal reflux during $\mathrm{pH}$ monitoring. Dig Dis Sci. 2005; 50(10): 1916-20.

23. Tahira R, Naeemullah M, Akbar F, Masood MS. Major phenolic acids of local and exotic mint germplasm grown in Islamabad. Pak J Bot. 2011; 43: 151-4.

24. Friedman M, Kim SY, Lee SJ, Han GP, Han JS, Lee $\mathrm{KR}$, et al. Distribution of catechins, theaflavins, caffeine, and theobromine in 77 teas consumed in the United States. J Food Sci. 2005; 70: C550-9.

25. Marriott BM. Functional foods: an ecologic perspective. Am J Clin Nutr. 2000; 71: 1728S-34S.

26. Bell SJ, Goodrick GK. A functional food product for the management of weight. Crit Rev Food Sci Nutr. 2002; 42(2): 163-78.

27. Tea - Preparation of liquour for organoleptic evaluation and testing. Institute of Standards and Industrial Research of IRAN. ISIRI number 5608. Available from: http://standard.isiri.gov.ir/StandardFiles/5608.htm

28. Moslehishad M, Ehsani MR, Salami M, Mirdamadi S, Ezzatpanah H, Niasari Naslaji A, et al. The comparative assessment of ACE-inhibitory and antioxidant activities of peptide fractions obtained from fermented camel and bovine milk by Lactobacillus rhamnosus PTCC 1637. Int Dairy J. 2013; 29(2): 82-7.

29. Annegowda HV, Anwar LN, Mordi MN, Ramanathan S, Mansor SM. Influence of sonication on the phenolic content and antioxidant activity of Terminalia catappa L. leaves. Pharmacognosy Res. 2010; 2(6): 368-73.

30. RaghaVendra M, Reddy Araveeti M, Raghuveer Yadav P, Sudharshan Raju A, Siva Kumar L. Comparative studies on the in vitro antioxidant properties of methanolic leafy extracts from six edible leafy vegetables of India. Asian J Pharm Clin Res. 2013; 6(3): 96-9.

31. Sharif R, Ahmad SW, Anjum H, Ramzan N, Malik SR. Effect of infusion time and temperature on decaffeination of tea using liquid-liquid extraction technique. J Food Process Eng. 2014; 37(1): 46-52.

32. Shrivas K, Wu HF. Rapid determination of caffeine in one drop of beverages and foods using drop-to-drop solvent microextraction with gas chromatography/mass spectrometry. J Chromatogr A. 2007; 1170(1-2): 9-14.

33. Dalluge J, Nelson BC. Determination of tea catechins. J Chromatogr A. 2000; 881(1-2): 411-24. 
34. Bailey RG, McDowell I, Nursten HE. Use of an HPLC photodiode-array detector in a study of the nature of black tea liquor. J Sci Food Agric. 1990; 52: 509-25.

35. Vuong QV, Roach PD. Caffeine in green tea: its removal and isolation. Sep Purif Rev. 2014; 43: 15574.

36. Horie H, Kohata K. Analysis of tea components by high-performance liquid chromatography and highperformance capillary electrophoresis. J Chromatogr A. 2000; 88(1-2): 1425-38.

37. Nassiri Rad R, Haddad Khodaparast MH, Elhami Rad AH, Roufigari Haghighat S. A study on the effect of harvesting season and brewing condition on total polyphenole content in the Iranian green tea. Iranian Food Sci. Technol. Res. 2013; 22(4): 349.

38. Gramza-Michalowska A, Korczak J. Polyphenolspotential improvement factor. Am J Food Technol. 2007; 2(7): 662-70.

39. Karori SM, Wachira FN, Wanyoko JK, Ngure RM. Antioxidant capacity of different types of tea products. Afr J Biotechnol. 2007; 6(19): 2287-96. 